\title{
Remuneration, Retention, and Reputation Incentives for Outside Directors
}

\author{
David Yermack \\ Department of Finance \\ Stern School of Business, New York University \\ 44 West $4^{\text {th }}$ St., Suite 9-160 \\ New York, NY 10012 \\ (212) 998-0357 \\ dyermack@stern.nyu.edu
}

October 2002

\begin{abstract}
I study incentives received by outside directors in Fortune 500 firms from compensation, replacement, and the opportunity to obtain other directorships. Changes over time in the value of equity compensation create considerable variation in director pay. Board members of the most successful firms earn millions of dollars within their first five years, a marked change in the historical pattern of rewards for directors. I also find statistically significant evidence that outside directors' replacement and total board seats held are associated generally with company performance. Previous research had only shown these relations to apply under extreme circumstances such as financial distress.
\end{abstract}

I appreciate helpful comments from Jay Hartzell and Anil Shivdasani. 


\section{Remuneration, Retention, and Reputation Incentives for Outside Directors}

\section{Introduction}

What causes outside directors to monitor managers, rather than collude with them? Fama and Jensen (1983) posit the existence of a market for outside directors' services, conjecturing that, "Our hypothesis is that outside directors have incentives to develop reputations as experts in decision control. . . They use their directorships to signal to internal and external markets for decision agents that they are experts. . . The signals are credible when the direct payments to outside directors are small, but there is substantial devaluation of human capital when internal decision control breaks down. ..”

To date most studies of the market for outside directors have focused on directors' success in accumulating seats on additional boards, finding some evidence that fewer offers for new directorships occur for the board members of firms that perform poorly. However, very little research into outside directors has examined the most direct incentives - compensation and replacement - that form the backbone of rewards for company executives. Exceptions such as Gilson (1988) and Harford (2001) tend to focus on extreme circumstances such as financial distress or hostile takeovers. For the vast majority of firms that do not face these crises, we have little evidence that outside directors face significant performance incentives. 
This paper investigates the range of incentives received by outside directors, studying a panel of 734 directors elected to the boards of Fortune 500 firms between 1994 and 1996. I follow each director for five years after election, tracking compensation received, appreciation of equity compensation, other board seats obtained, changes in disclosed conflicts of interest, and departures from the board. All of these variables represent potential sources of motivation or discipline for an individual director. Studying how director incentives evolve over time seems especially important, because most new outside directors arrive at their firms with close to zero equity, little direct knowledge of the company's operations, and their reputations dependent almost entirely on their current or former full-time jobs. As time passes these relations change, as directors accumulate equity in the firm and are more likely to influence - and be rewarded for - the company's strategy and performance.

I find statistically significant evidence that outside directors receive positive performance incentives from compensation, turnover, and opportunities to obtain new board seats. The results apply to a broad cross-section of firms in all performance ranges, not just those with extreme performance that have been the focus of prior research. Rewards from compensation appear to have much more economic significance that those from opportunities to obtain other board seats or the threat of removal. For directors of the best performing firms, financial rewards can be extremely large, growing into millions of dollars over the directors' first several years. These findings represent something of a contrast to the idealized market for directors' services envisioned by Fama and Jensen, who hypothesized that the market works best when "payments to outside directors are small" relative to the after-market incentives related to the directors' reputations. 
One reason that director compensation and replacement may have received little attention in past research is that both of these incentive mechanisms are subject to severe conflicts of interest, as the board generally sets its own compensation and, in the absence of a rare proxy fight, decides on its own members' continuation in office. However, external forces in recent years have constrained boards' ability to overpay or entrench themselves with impunity. Institutional investors have promulgated standards for corporate governance and attempted to enforce them through a mix of direct meetings, shareholder resolutions, and media campaigns against companies that they target for poor governance. In noteworthy cases such as Archer Daniels Midland, American Express, W.R. Grace and Walt Disney, these types of pressure have led directly to replacement of certain outside directors and/or changes in the structure of board compensation. Other firms with suboptimal governance have no doubt taken note of these examples and acted likewise.

The remaining sections of the paper are organized as follows. Section 2 describes the sample and data collection. Section 3 presents analysis of four incentive mechanisms for outside directors: compensation, losing their board seats, obtaining additional directorships in other firms, and the possibility of obtaining special treatment from the company that would "corrupt" an independent outside director by converting him or her to "grey" or "affiliated" status. Section 4 concludes the paper.

\section{Data description}

Data for this study is based on the panel of director appointments examined in Shivdasani and Yermack (1999). That paper included 766 outside director appointments in Fortune 500 
firms announced in proxy statements between 1994 and 1996, excluding firms in the financial and electric utility industries, which tend to have larger boards dominated by local business executives. Outside directors are classified according to the standard taxonomy of "independent" and "grey," with the latter category including those with disclosed conflicts of interest. These conflicts include special consulting contracts for the director, a significant business relationship between the firm and the director's main employer, a family relationship between the director and a top manager, and interlocking board memberships between the director and the CEO. I drop 29 observations from the original sample for directors who joined boards of sample companies due to acquisitions, since these directors were not "new" to their positions and can be expected to have accumulated ownership and power within the board greater than a rookie director appointed from outside. An additional four observations were reclassified from grey to inside and also dropped, and one new observation missed in the original data collection was added to the sample. The sample for this paper therefore includes 734 new outside directors, 607 independent and 127 grey. These 734 appointments involve 684 individual people (39 persons are appointed to two boards, four persons join three boards, and one person joins four). In seven cases, outside directors become officers of the company at some point after joining the board. These directors all remain on the board as insiders, but because I am interested in incentives faced by outside directors, I stop tracking these directors at the point at which they move inside.

I gather data about directors by reading their biographies in the first five proxy statements published by the firm in which they appear. Twenty-eight percent of the directors do not survive in office for at least five years, leaving due to retirement from the board (16 percent), de-listing 
of the company (11 percent), and, as mentioned above, a change in status from outside to inside (1 percent). Slightly more than one-fifth of new directors are women and most own virtually no stock when appointed, with a median ownership position of 0.0004 percent of shares outstanding.

I gather from proxy statements annual observations for each director about compensation received, board seats held in other firms, stock owned, committee memberships, and disclosed conflicts of interest involving the company or one of its top managers. A large number of directors join their boards by appointment rather than shareholder election midway through the year before they first appear in a proxy statement. In these cases it can be difficult to ascertain whether they received partial or complete directors' fees; I generally assume that they have received the full fee unless specific disclosure or data about the director's stock ownership indicate otherwise; especially in the case of equity compensation, most firms appear to report carefully when a director receives less than the entire year's standard fee. Many boards that award equity compensation make very large awards to new directors in order to give them a critical mass of ownership in the firm, so it is important not to overlook compensation received during this first year or part-year on the board.

Directors receive compensation in the form of both shares of stock and stock options, sometimes simultaneously. Most company disclosures for this equity pay are much briefer for directors than for executives, so I generally do not know basic terms of these awards such as the date, the stock price when awarded, or terms such as vesting or restrictions on sale. I therefore make a range of assumptions for use in valuing equity compensation and its subsequent appreciation. I assume that equity pay is awarded when the stock price equals the average price 
for the year, computed from the twelve monthly closing stock prices. All stock options are assumed to be awarded at-the-money with ten year lives, in line with the overwhelmingly prevailing practice. When firms give directors the opportunity to choose between cash and equity compensation, or deferral of cash compensation into an equity-based instrument, I assume that they choose the maximum amount of cash pay permitted unless disclosure indicates otherwise. This assumption assures that subsequent calculations about the importance to directors of equity compensation generally represent lower bounds. I assume no early exercise of options and no sale of stock compensation, at least for the first five years. I value options using the Black-Scholes method. Volatility and dividend yields for each firm-year are obtained for the vast majority of observations from the ExecuComp database; when firms are not covered by ExecuComp, I use the volatility and dividend rate assumptions reported by the company in its footnote about stock option compensation published in its annual Form 10-K. I value equity appreciation through the end of the fiscal year preceding the fifth proxy statement in which the director appears, using the year-end stock price.

Table 1 presents information about the annual compensation received by outside directors in the sample. A little under half of all directors receive stock options and about the same proportion receive direct stock awards, though a large majority (77 percent) receive at least one of these two types of equity pay in a given year. The average retainer from all sources is worth around $\$ 70,000$ when awarded, though the data is skewed by some firms making large annual equity awards worth many hundreds of thousands of dollars. Additionally, directors receive an array of lesser compensation in the form of meeting fees, committee fees, insurance coverage, and other fringe benefits; Perry's (2000) data indicates that other cash fees increase the 
annual retainer by about one-third. To keep the data collection and analysis tractable, I ignore these other types of director compensation, none of which takes the form of equity and therefore does not appreciate in value over time.

\section{Analysis of directors' incentives}

The following sections analyze rewards to outside directors from four sources: compensation (section 3.1), loss of the board seat if the company performs poorly (section 3.2), obtaining directorships in other companies if the firm performs well (section 3.3), and the possibility of an independent director shifting to grey status via the receipt of special payments or other benefits (section 3.4).

\subsection{Compensation}

Corporate directors have never received bonuses or other incentive compensation tied to the success of the firm or their individual performance in the boardroom. Instead, director compensation for decades has followed an almost identical structure across firms: a fixed annual retainer (and smaller additional fees for things such as meeting attendance), which can usually be deferred in a company-sponsored plan to avoid immediate income taxation. Retirement or other pension benefits were once widespread but mostly disappeared in the mid-1990s after institutional investor protest. The fixed retainer, which is set by the board or a subcommittee that deals with compensation or governance issues, has historically tended to exhibit little variation across firms or industries with anything other than company size.

Since the late 1980s an increasing number of firms have paid the annual retainer in 
equity, using either restricted stock or stock options. While the value of these fixed awards has exhibited little relation to firm performance, their subsequent appreciation has had the effect of tying directors' rewards much more closely to firm performance than before. Perry (2000) and numerous industry surveys document the increasing use of equity in boards' annual retainers. In my sample, the average annual retainer paid to directors was $\$ 69,435$. Equity compensation delivered 62 percent of the total retainer value across the sample, with option awards (40 percent, valued on a Black-Scholes basis) having a more important role than stock awards (22 percent). Cash compensation made up the remaining 38 percent. However, these statistics are somewhat misleading as an indicator of the representative director's compensation, since the median option award is zero.

Figure 1 shows that the use of equity compensation has the effect of significantly increasing outside directors' ownership stakes as their tenure increases. Most outside directors own little or no stock when first elected (by the time of the first ownership report in a proxy statement, many directors will have been serving on the board for a part-year, so that the ownership reported may well have come from directors' fees and not personal investment). In my sample, the median director's fractional ownership in the firm increases by nearly a factor of 12 when measured in the fifth proxy statement following his election compared to the first proxy statement. At this point, fifth-year directors own a median $\$ 375,000$ worth of their firm's equity, up from $\$ 21,000$ at election (a rising stock market over most of the sample period explains why the dollar value of ownership increases more rapidly than percent ownership). Mean values for outside director ownership percent and value (not tabulated) are much higher but are heavily skewed by a tiny handful of individuals with billion-dollar investments. 
Table 2 shows the distribution of remuneration for directors over their first five years, broken into two pieces: the value of fixed retainers when awarded, shown in the first column, and the subsequent appreciation of stock and option awards, shown in the second column. All option values and value changes are calculated using Black-Scholes methodology, assuming that the options (which generally have ten-year lives) are retained and not exercised by the director over the first five years. The table is restricted to the 529 directors who remain on the board at least through the date of the fifth annual proxy statement after their election.

Data in Table 2 indicate that changes over time in equity award values introduce considerable variation into the remuneration of outside directors. Taking both fixed fees and appreciation into account, the inter-quartile range for director income ranges from $\$ 186,000$ in the $25^{\text {th }}$ percentile to $\$ 428,000$ in the $75^{\text {th }}$ percentile (I do not apply a time value of money discount factor, which would not change the basic message conveyed by the data). In the upper tail of the distribution, outside directors earn extremely high rewards. Forty-two directors, or about 8 percent of the sample, received more than $\$ 1$ million from their retainers over their first five years’ service, and four directors received more than $\$ 20$ million. ${ }^{1}$ Though the most enriched directors worked for computer and technology firms that arguably benefitted from a price bubble in the late 1990s, other outside directors among the group of millionaires came from such diverse firms as General Electric, Costco, Ameritech, Viacom, Target, ConAgra and Gap

\footnotetext{
${ }^{1}$ The maximum remuneration of more than $\$ 56$ million was received by Michael Miles, former CEO of Philip Morris, who was elected to the board of Dell Computer in 1995. Another Dell director elected in the same year did almost as well. Dell made large annual stock option awards to outside directors and gave them the opportunity to exchange their cash retainers for more options, which Miles did, all during a period when its stock soared and split 64:1. Miles owned nearly two million options, deep in the money, after his first five years as a director. Further director option awards were scaled back by Dell in 1998 "in the best interests of the company and its stockholders." Ownership data in proxy statements indicate that Miles earned tens of millions more from personal investments in Dell stock.
} 
Stores.

The prospect for new outside directors of some firms to earn millions of dollars in a relatively short period of years, entirely from their directors' fees rather than personal investments, represents a marked change in the pattern of rewards for board service. Since a conscientious outside director may spend about 250 hours a year on company business, and many outside directors serve on three to five boards (and sometimes more), the data imply that director compensation when a firm succeeds has reached near-parity with the pay of top executives.

Figure 2 provides insight into the strength of the pay-performance relation for the outside directors in my sample. The figure shows mean and median director remuneration over five years tabulated according to performance decile, with performance measured as the firm's stock return minus the CRSP value-weighted market index. The figure also shows the percentage of directors in each performance decile who earn more than $\$ 1$ million over their first five years. Since an increasing stock price directly drives appreciation in a director's stock and option awards, and since this award appreciation contributes the majority of variation to total remuneration, a pay-performance relation arises almost mechanically. Though compensation is relatively flat across the middle performance deciles, stock returns for firms also do not vary greatly in this range. At the upper tails of the performance distribution director compensation increases markedly. Moving from the eighth to the ninth and tenth performance deciles, median five-year director remuneration rises from $\$ 338,000$ to $\$ 468,000$ and $\$ 718,000$, respectively, and the fraction of directors receiving million-dollar pay increases from 4 percent to 15 percent and 45 percent, respectively. Put another way, median director remuneration increases by 37 percent 
in the ninth performance decile compared to the eighth, and by an additional 53 percent in the top decile compared to the ninth. At the other end of the distribution, median remuneration falls by 15 percent in the second decile compared to the third, and by an additional 30 percent in the bottom decile compared to the second (the dollar value changes are not as great as at the top, since remuneration must be bounded below at zero).

The incentive effects of performance-based remuneration for outside directors represent a marked change compared to director pay in the 1980s and before. For comparison purposes, I use data about directors' compensation in a sample of 456 Forbes 500 companies with the same industrial exclusions as the current sample (no financial institutions or electric utilities). The data are described more fully in Yermack (1995). In that sample, which covers the years 198491, stock option awards accounted for 10 percent of the total annual retainer value, compared to 40 percent in the current sample (the unit of observation for that sample is a company-year, instead of a director-year as done in this paper, so the comparison is not perfect). Directors fees in the older sample exhibit a strong association with company size.

Table 3 presents ordinary least squares regressions of the year-over-year change in the retainer for outside directors (calculated by taking the log of the ratio) against the change in sales (again calculated as the log of the ratio) and the net-of-market stock return (compounded continuously). Stock option awards in both samples are valued using Black-Scholes methodology. The regression coefficients in the table can be interpreted as estimated elasticities of the directors' retainers with respect to firm size and equity value, respectively. For the present sample I use observations beginning with year 2 of each director's service, since many firms today give abnormally large equity awards when an outside director first joins a board and 
such "starter" awards were not included in the comparison sample. Estimates in Table 3 for the models' intercepts indicate that director fees exhibited a secular pattern of 7 to 8 percent annual increase during the $1980 \mathrm{~s}$, a trend that has risen to the range of 9 to 10 percent today. The estimated elasticity with respect to firm size previously lay in the range of .10 to .11 but has surprisingly turned negative in more recent years, in the range of $-0.08 .^{2}$ (Since the model's intercept exceeds +.09 , a firm that doubles in size would not see its directors' fees shrink, but rather grow more slowly over time.) The estimated elasticity with respect to equity value has also fallen, from the previous range of .06 to .07 to a new range of .03 to .04 . The regression estimates suggest two key interpretations. First, directors' fees appear largely to have been unlinked from firm size today compared to the recent past. Second, the relation between directors' fees and equity value, which was never strong in the past, has also grown weaker. However, as the previous analysis shows, the increasing use of equity-based retainers today gives directors strong pay-performance incentives from changes in the awards' value over time, an effect not present in the past when retainers were mostly cash-based.

\subsection{Company performance and director turnover}

Outside director turnover is much lower than turnover for excutives. I use a binary $(0,1)$ variable to measure director turnover and set it equal to 1 for a given year's observation if a director does not appear in the next year's proxy statement. For firms that are de-listed due to acquisitions and a few bankruptcies, I set the turnover variable equal to missing for the year of de-listing. The turnover variable equals zero for the seven outside directors who become

\footnotetext{
${ }^{2}$ Numerous executive compensation studies have estimated this elasticity around .30 for top managers, a statistic that has remained surprisingly stable over time. See Baker, Jensen, and Murphy (1988) and Murphy (1999).
} 
insiders during the sample period, though I do not include them in the sample after their last year as outsiders. The unconditional rate of director turnover in my sample of directors with five years service or less is 4.6 percent.

For CEOs and other executives, the threat of replacement represents an important complement to compensation in the array of incentives that mitigate agency problems. For outside directors, the threat of replacement is more attenuated, since directors do not report to a higher authority who might fire them for poor performance. Nevertheless, one would expect directors of under-performing companies to face pressure to leave their posts from institutional investors or major shareholders. These directors might also be tempted to abandon the firm in order to contain damage to their reputations, evade legal liability, and escape the workload involved in restructuring an under-performing firm. Under any of these scenarios, if poor performance of the company leads to departure of the director, he will have lost future income and the opportunity to increase his reputation as an expert in corporate oversight.

A significant body of research has examined the connection between CEO performance and turnover, but similar research into outside directors has been scant, generally limited to extraordinary circumstances such as mergers or bankruptcies. Gilson (1988) studies turnover of outside directors in firms that experience financial distress and finds an annualized departure frequency of 19.5 percent during the distress period. Harford (2001) finds that the overwhelming majority of outside directors lose their board seats after a firm is acquired, an unsurprising result since the firm ceases to exist (a small number will join the board of the acquirer). Brown and Maloney (1999) study boards of companies that make acquisition attempts. Among the bidders whose offers lead to the lowest announcement stock returns, 
higher turnover of outside directors occurs in advance of the bid, a result that may be consistent with a more general connection between poor performance and director turnover.

Figure 3a compares cumulative turnover rates for my director sample with the departure rates for CEOs of the same companies; the chart is constructed by calculating the unconditional turnover rate for all directors and CEOs in their first years, their second years, and so forth, and cumulating these average rates geometrically. While the average age at appointment is 54 for both outside directors and CEOs, the figure shows that during their first five years in office, directors leave their positions at a frequency about 60 percent of the departure rate for CEOs. Figure $3 \mathrm{~b}$ compares director and CEO turnover by age and illuminates clear disparities between the two groups (the figure is not meaningfully different if the sample is restricted to CEOs also serving in their first five years). In line with the retirement policies of most U.S. firms, a large majority of CEOs leave their positions at some point between ages 60 and 69. However, outside director turnover in the $60 \mathrm{~s}$ age range is rare and virtually the same as for directors in their $40 \mathrm{~s}$ and 50s. At age 70 and above, the annual departure frequency is about 20 percent for both outside directors and CEOs. (Although not always reported in proxy statements, a significant number of sample firms report having mandatory retirement ages for outside directors, often at some age between 70 and 75$)$

I estimate logistic regressions to evaluate whether a performance-turnover connection exists for outside directors under general business conditions, a relation not previously studied in the literature. I measure performance using the firm's annual stock return, minus the return for the CRSP value-weighted index, with both returns compounded continuously before they are differenced. I include control variables to account for other factors that might influence director 
turnover: percent ownership in the firm, years of service, indicator variables for female directors, grey directors, members of the audit and compensation committees, directors ages 65-69 and 70 and over, and indicator variables for calendar years.

Several papers document a connection between the departure of the CEO and contemporaneous changes in the board of directors. See Farrell and Whidbee (2000) and Hermalin and Weisbach (1988). To reflect this known link between CEO turnover and director turnover, I use two indicator variables: (i) an indicator that takes the value of 1 in years in which the $\mathrm{CEO}$ also leaves his position, and (ii) an indicator that equals 1 in all years subsequent to the departure of the CEO who was in office when the director first joined the board.

Table 4 presents the logit regression estimates and with robust standard errors, which are used in all remaining regressions to adjust for the possibility that error terms are correlated for certain subgroups (for instance, the several dozen individuals who appear in the sample more than once). Coefficient estimates in Table 4 indicate a negative and significant association between director turnover and firm performance. ${ }^{3}$ Similar to the findings of papers studying CEO turnover, the director performance-turnover effect depends mostly on performance in the departure year itself, as the coefficient estimate for company performance lagged one year is near zero. While the data indicate an association between poor firm performance and departures of outside directors, one might attribute this pattern to many different motivations. Director turnover might be disciplinary in nature, if major shareholders or institutional investors respond to poor performance by agitating for changes in the board. Alternatively, directors might

\footnotetext{
${ }^{3}$ Re-estimating the regressions using an accounting measure of return on assets also leads to negative coefficient estimates, but they are not generally significant.
} 
voluntarily leave poorly performing firms at a high rate, to contain the damage to their reputations, to limit legal liability, or to avoid the higher workload that boards usually undertake when performance drops (Vafeas, 1999). Since the news media rarely reports director departures and almost never illuminates the reasons for an individual director's leaving, one cannot easily partition director turnover into "forced" and "voluntary" sub-samples as many studies do for CEO turnover.

The estimates also illustrate a close connection between CEO turnover and the departure of outside directors. The indicator for years in which the CEO leaves office has a strongly positive and significant estimate, a prima facie indicator that disciplinary turnover applied to CEOs might spill over to cause replacements of some outside directors who may be allied with the executive. The indicator for the years following the departure of the CEO who had been in office when the director originally joined the board is similarly positive and significant. The latter variable might capture several effects. The director might lack a personal relationship with the new CEO that he enjoyed with his predecessor and therefore feel less inclined to continue serving. The new CEO may also wish to remake the board with directors of his own choosing, and tacitly encourage directors appointed by his predecessor to leave. Notwithstanding the link between CEO turnover and director turnover, however, director turnover is itself significantly impacted by poor performance; if the two indicator variables for CEO turnover are omitted from the regression, the coefficient estimate for the performance variable changes only modestly, from -0.56 to -0.60 .

Several additional control variables in the turnover regressions have interesting estimates with statistical significance. As suggested by Figure 3b, directors over age 70 retire at a 
significantly higher rate than other directors. Female directors exhibit significantly lower turnover rates than male directors, a result consistent with the well publicized efforts of many firms to increase the diversity of their boards. Members of key board committees, especially the compensation committee, also exhibit less turnover than other directors. ${ }^{4}$ These directors may have high value to the board due to their specific knowledge of key areas, and may have influence in corporate governance that insulates them somewhat from disciplinary turnover. Reestimating the model after including indicator variables for different full-time job occupations held by the outside directors has virtually no impact on the results, and none of the occupation indicator variables has a significant estimate.

The statistically significant association between poor company performance and higher outside director replacement represents a novel finding, but it is less clear that the relation has sufficient strength to be economically important. I assess the economic significance of the performance-turnover relation for outside directors in tests reported in Table 5. This table uses a transformation of the logit regression model to estimate the marginal effects upon the probability of departure of a unit change in key regressor variables; I calculate these marginal effects by taking the partial derivative of the logit likelihood function and substituting in the regression coefficient estimates and sample means of each variable. For comparison purposes, I estimate a logit turnover model for the CEOs of my sample firms and report its estimated marginal effects side-by-side with those from the model for outside directors.

Estimates in Table 5 indicate that the performance-turnover relation operates more than

\footnotetext{
4 This result does not extend to an indicator variable for directors who are members of the nominating committee, which has an estimate very close to zero if included in the model. I omit this variable because it is missing for numerous sample companies that have no nominating committee.
} 
three times more strongly for CEOs than for outside directors; underperforming the market by 100 percent (in the continuously compounded specification used, this would equal 63 percent under-performance over the course of a year) is associated with an increase in the probability of CEO turnover by 7.3 percentage points, and of outside director turnover by 2.2 percentage points. Since the standard deviation of the performance variable is about 0.39 , these effects seem modest in economic terms. However, they are certainly important in relation to the unconditional frequency of outside director turnover of .046 in the sample; a one standard deviation decline in the firm's performance would make the replacement of outside directors almost one-fifth more likely than otherwise. If the CEO leaves office during a given year, the probability of the outside director leaving rises by 3.3 percentage points, and in subsequent years it remains higher by 2.0 percentage points. Again, these effects are large compared to the unconditional outside director turnover rate of 4.6 percent.

To investigate the performance-turnover relation for outside directors in more detail, I display in Figure 4 the departure rates for directors (again compared with their CEOs) according to deciles of the stock return performance variable. Along with the actual departure rates, the chart shows predicted rates in each decile calculated from logit coefficient estimates from the model in Table 5. The chart shows dramatically higher departure rates than expected for both directors and CEOs in the lowest performance decile, and rates generally close to the predicted level throughout the rest of the distribution. The data resemble the actual and predicted decileby-decile turnover frequencies reported by Warner, Watts and Wruck (1988, Table 7) in their study of top management turnover in large firms between 1963 and 1978. Like that earlier study, I find a strong concentration of turnover at the very bottom of the performance 
distribution, suggesting that performance must be extremely poor for both the CEO and director departure probability to increase meaningfully.

Finally, I estimate logit turnover regressions separately for each individual year of director service, to see whether the performance-turnover link strengthens or weakens as directors acquire seniority. The key coefficient estimate for the stock return performance variable is strongly negative in years 1 and 2, with estimates of -1.88 (standard error 0.62 ) and $-1.43(0.39)$, respectively. After that the coefficient moves close to zero, with no statistical significance, in years 3, 4, and 5. For outside directors, therefore, departures linked to poor performance of the firm appear to occur early in directors' tenures, if at all. This finding contrasts with similar analysis for CEOs of my sample firms, as annual logit turnover regressions indicate a negative, significant relation between CEO departure and performance at every year of seniority, with little pattern over time. Moreover, the strength of the performance-turnover relation for new outside directors is at rough parity or even stronger than that estimated for new CEOs.

\subsection{Directorships in other firms}

Outside directors who develop reputations as skillful monitors might acquire additional directorships in other firms. If a new outside director can reasonably expect to serve 10 to 15 years, and if the expected remuneration for a director approaches $\$ 100,000$ per year (including

meeting fees and fringe benefits), each additional directorship probably has a present value in the neighborhood of a million dollars, along with the potential for appreciation of equity pay.

A growing literature illustrates that outside directors who oversee their firms 
successfully, or take actions in the interests of shareholders, are more likely to acquire new directorships. Most of these papers have focused on the change in directors' other board seats in the aftermath of some extraordinary situation or event, rather than the general performance of the firm. See Gilson (1988) (financial distress); Farrell and Whidbee (2000) (dismissal of CEO); Harford (2001) (sale of the firm); Coles and Hoi (2001) (opting out of anti-takeover legislation). ${ }^{5}$

Ferris, Jagannathan, and Pritchard (2002) come closest to studying whether the overall performance of a company affects the number of board seats by its outside directors. The authors find a positive association between performance and directors obtaining new board seats. However, a number of aspects of the authors' research design limits the applicability of the results. For outside directors who are not retired, performance is measured with respect to the director's primary employer, rather than for the firm in their sample on whose board he serves. For directors who do not have full-time jobs, performance is measured as an average across all companies on whose boards they sit, rather than for the sample firm. The authors measure performance only by accounting profitability rather than stock market returns. Finally, their regressions for the acquisition of directorships rely on a $(0,1)$ binary dependent variable that equals 1 if any new directorships are obtained; this specification takes account of neither the number of additional directorships received, nor the possibility that directors could lose rather than gain external board seats (this truncation of the dependent variable appears in several of the other studies cited above).

\footnotetext{
${ }^{5}$ Related research studies company performance and the outside directorships obtained by company executives. Kaplan and Reishus (1990) find that if a firm reduces its dividend, the likelihood falls of its executives gaining additional directorships. Brickley, Linck and Coles (1999) find a connection between company performance during the CEO's final four years in office and the number of directorships he holds after retiring, though the result holds only for accounting performance and not stock performance. See also Booth and Deli (1996) and Avery, Chevalier, and Schaefer (1998).
} 
Figure 5 tabulates the distribution of the change in other board seats held by the outside directors who serve for the entire five-year period of my sample. The chart, which is limited to directorships held in public companies, shows that a $(0,1)$ binary variable measuring the change in directorships does not do justice to the richness of the data; directors gain as many as five other board seats over the sample period, and a substantial number experience a net loss in board seats. The distribution has a mean change of +0.20 directorships (standard deviation 1.28) and a median of 0 .

I regress the four-year change in board seats against the company's net-of-market stock returns during the director's tenure in office. I include indicator control variables for various director occupations, grey status, and gender. I include as a variable the company's rank in the Fortune 500, in the belief that appointment to the boards of the most visible public firms will by itself bring reputational benefits that increase with the prominence of the company. I also add to the model the number of other board seats already held by the director. One would expect new board seats to have a mechanical negative association with this variable, since directors serving on zero boards could only gain seats, while those serving on very many boards are likely to refuse new seats beyond a certain point. Table 6 reports the regression estimates. The current year stock return refers to the fiscal year ended prior to publication of the fifth proxy statement in which the director appears, i.e., the director's fourth year of service. I find that more than one year's lag of the performance model does not contribute to the model, so I do not report historical stock returns beyond two years.

Estimates in Table 6 show a positive association between the company's performance in the previous two years and the net acquisition of new board seats by outside directors over the 
four years since their appointments. However, only the lagged performance variable has a significant estimate. If a smaller time period is used to measure the acquisition of directorships, such as the change over the director's first two or three years on the board instead of four years, I do not obtain significant results, suggesting that the market for directors' services takes time to assess and assimilate the monitoring ability of newly appointed directors. Using accounting profits instead of stock returns as the measure of performance also leads to positive estimates, but they are not significant. Grey directors receive fewer new board seats than independent ones, a result indicating that firms are reluctant to recruit directors who have exhibited conflicts of interest on other boards.

Given the stock performance variable's standard deviation of 0.39 , the coefficient estimates for this variable and its lag suggest that one standard deviation out-performance of the market for two years will lead to an expected increase of about 0.2 directorships for each outside director, a relation that appears to have some economic significance as well as statistical significance, given the potential remuneration described earlier.

While the analysis indicates a positive association between firm performance and the opportunities for outside directors to serve on other boards, the change in directorships held is a somewhat imperfect measure of any director's reputation. On occasion directors may lose board seats by taking actions in shareholders' interest, such as agreeing to sell the firm or openly challenging the policies of ineffective managers. The raw number of board seats held may also become negatively associated with a director's monitoring capacity beyond a certain point, since directors sitting on very many boards may become inattentive or susceptible to cronyism. 


\subsection{Special treatment of outside directors}

Some outside directors may obtain special benefits from their service, such as personal consulting contracts with the corporation or a stream of business for their main employers. Others may enter into interlocking relationships with the CEO, obtaining mutual benefits by sitting on one another's boards or sitting together on a third board. The prospect of joining a board as an independent outside director and subsequently entering into one of these "grey" relationships may provide a form of incentive.

The possibility of independent directors becoming "corrupted" into grey status over time is suggested by data reported in Shivdasani and Yermack (1999), tabulated for the same sample used in this paper. The overall composition of the boards in the sample includes 25.8 percent grey directors, but only 10.6 percent of newly appointed directors have grey status. The disparity between these numbers could be explained by some combination of three effects: (i) grey directors serving longer tenures than independent directors; (ii) fewer grey appointments in recent years than in the past, or (iii) a pattern of "corruption" in which independent directors acquire conflicts of interest and become grey over time. Possibility (i), that grey directors might serve for longer tenures than independent directors, is not supported by the data. The unconditional turnover frequency of grey directors is higher than for independents, and regression estimates in Table 4 indicate a higher turnover probability for greys as well (though the difference from independents is not statistically significant).

Data also do not support the hypothesis that independent directors might be systematically corrupted into grey status over time. Over the five years studied in the sample, I

find 30 independent directors ( 5 percent of the sample) acquiring grey status at some point, the 
large majority through the creation of interlocks with the CEO. However, these changes are almost exactly offset by 26 grey directors in the original sample losing their conflicts of interest and becoming independent, most often when the $\mathrm{CEO}$ with whom the grey director was interlocked retires while the director remains on the board. Special consulting contracts or other personal benefits for outside directors are rare in the sample, as only 1.6 percent have them disclosed in proxy statements in any given year.

An interesting question is whether shareholders might predict which independent directors are most likely to move to grey status over time. I define a $(0,1)$ "corruption" indicator variable that equals 1 if an independent appointee becomes grey at any point over their first five years on the board. I regress this variable in a probit model against percent ownership, indicator variables for the director's main occupation, the number of other boards on which the director sits, gender, age, indicators for committee membership, and the abnormal stock return that occurred when the director's appointment was originally announced. Among the occupational indicators, attorneys who join the board as independent directors exhibit a significant higher probability of turning grey; the result does not extend to other professional service providers such as investment bankers or consultants. Directors who sit on a large number of boards also are more likely to become grey, probably because they have a greater possibility for future interlocks with the CEO. Female directors are less likely than males to move from independent to grey status, though the result has borderline statistical significance. The abnormal stock return at the director's appointment has no association with the future probability of becoming grey.

I conclude that the prospect of extraordinary personal benefits plays little meaningful role 
as an incentive for outside directors. The explanation for the disparity between the recent rate of grey outside director appointments and the much higher cross-sectional average of grey outsiders already serving on boards appears to be due to a much reduced tendency to appoint grey directors now compared to the past.

\section{Conclusions}

In the past, few outside directors expected to become wealthy as a result of their board service. My investigation of outside directors appointed to Fortune 500 boards between 1994 and 1996 indicates that directors today receive much more lucrative compensation incentives than before. Most outside directors now receive a significant portion of their annual retainers in either stock or stock options. Changes over time in the value of these equity awards introduce considerable variation into director remuneration. A clear pay-performance relation exists for outside directors, with 45 percent of board members of companies in the top performance decile earning more than a million dollars in their first five years of board service, and significant differences in remuneration emerging at both ends of the performance spectrum.

I also find evidence that outside directors experience meaningful performance incentives from both the possibility of replacement and the attraction of new board seats in other firms. Both of these variables have significant relations with overall firm performance, under general business conditions and not just extreme circumstances such as financial distress or removal of the CEO.

Collectively these results suggest that directors' incentives to increase the value of the firm have strengthened considerably in recent years, validating the efforts of institutional 
investors to introduce reforms in director selection, evaluation, and compensation. 


\section{Figure 1}

\section{Ownership of outside directors}

Quartiles of the distribution of ownership for a sample of 734 outside directors elected to boards of Fortune 500 companies between 1994 and 1996. Ownership for each director is calculated as shares held divided by shares outstanding. All data are obtained from company proxy statements, with share holdings measured according to the SEC's definition of beneficial ownership. Data are tabulated separately for each of the director's first five years in office.

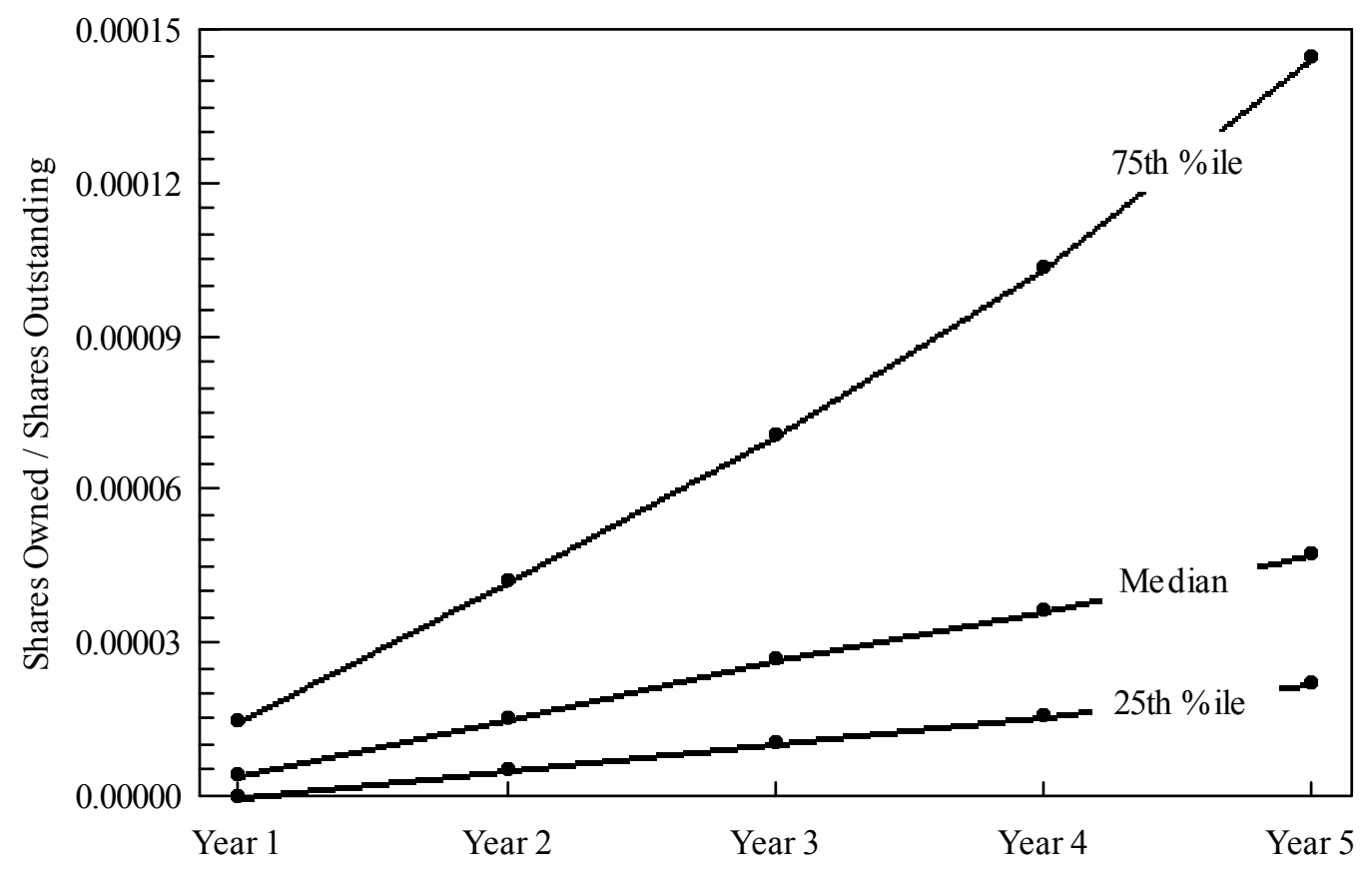

$\begin{array}{lrrrrr}\text { Median ownership (\%) } & \text { Year 1 } & \underline{\text { Year 2 }} & \underline{\text { Year 3 }} & \underline{\text { Year 4 }} & \underline{\text { Year 5 }} \\ \text { Median ownership } & \$ 21 & \$ 72 & \$ 154 & \$ 263 & \$ 375\end{array}$
(\$000) 


\section{Figure 2}

\section{Five-year value of compensation for outside directors,}

including appreciation of equity awards

Value of retainers received in their first five years of service for 527 outside directors of Fortune 500 companies elected between 1994 and 1996. The calculation includes the value of annual retainers paid in cash, stock, and stock options, as well as the subsequent appreciation of option and share awards. All option values, including appreciation, are computed using the BlackScholes method. Data are tabulated in five-year performance deciles, with performance measured as the firm's cumulative stock return minus the CRSP value-weighted index.

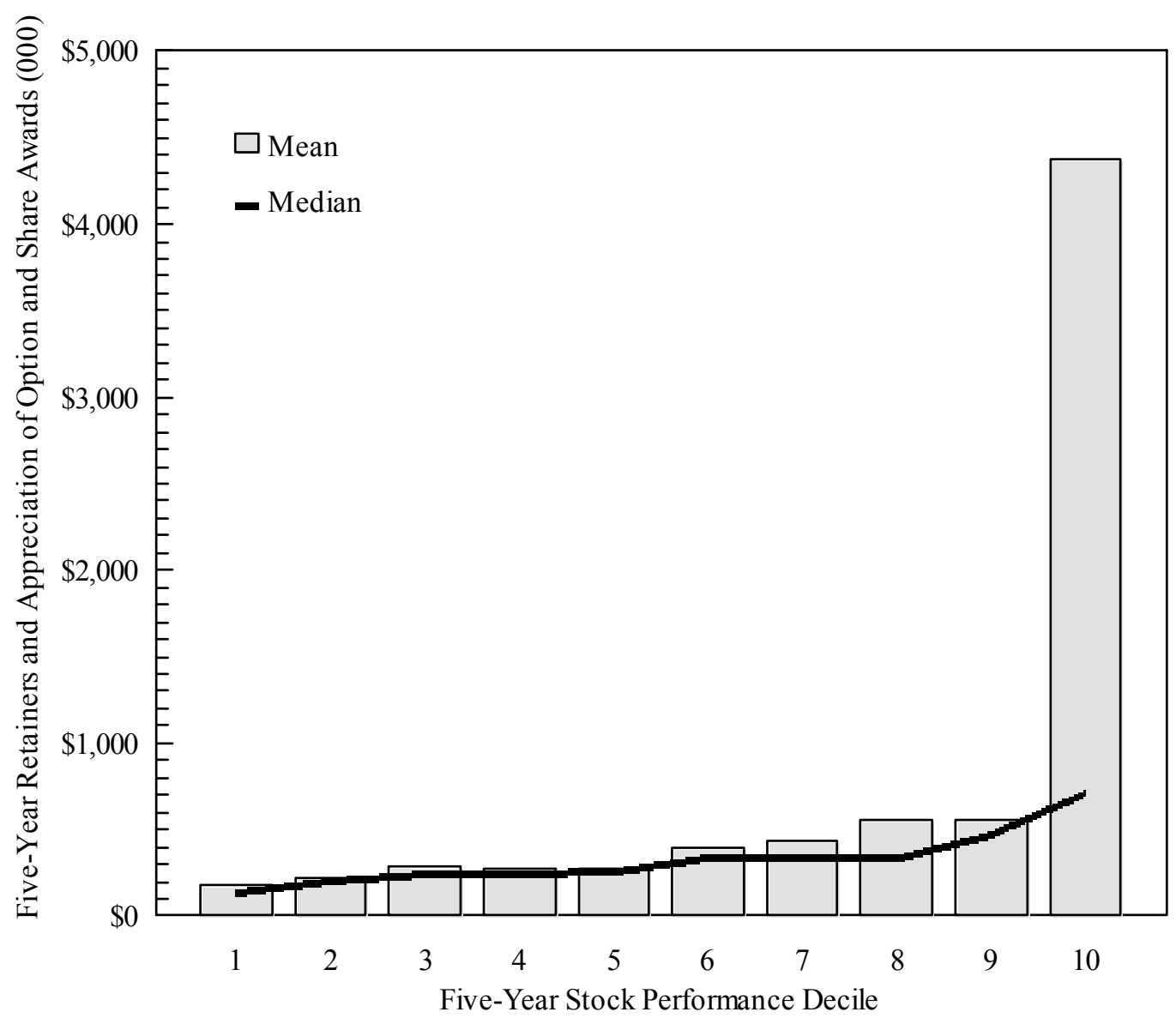

\section{$\underline{\mathbf{D}}$}

$\underline{\text { ecile }}$

Mean (000)

Median (000)

$\begin{array}{rrrrrrrrrr}\underline{\mathbf{1}} & \underline{\mathbf{2}} & \underline{\mathbf{3}} & \underline{\mathbf{4}} & \underline{\mathbf{5}} & \underline{\mathbf{6}} & \underline{\mathbf{7}} & \underline{\mathbf{8}} & \underline{\mathbf{9}} & \underline{\mathbf{1 0}} \\ \$ 180 & \$ 225 & \$ 282 & \$ 277 & \$ 273 & \$ 398 & \$ 440 & \$ 554 & \$ 560 & \$ 4,380 \\ \$ 145 & \$ 207 & \$ 243 & \$ 246 & \$ 254 & \$ 347 & \$ 338 & \$ 338 & \$ 468 & \$ 718 \\ 0 \% & 0 \% & 0 \% & 0 \% & 0 \% & 6 \% & 9 \% & 4 \% & 15 \% & 45 \%\end{array}$

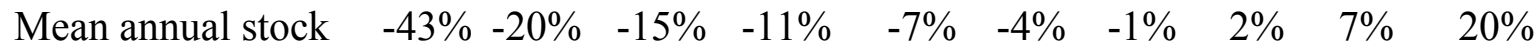
return, net of market 


\section{Figures $3 a$ and $3 b$}

\section{Retirement rates of outside directors and CEOs}

Retirement frequencies for a sample of 734 outside directors appointed to the boards of Fortune 500 companies between 1994 and 1996, compared with retirement rates for the CEOs of the same companies. Turnover is tabulated cumulatively by years in office and by age. Turnover due to acquisition or de-listing of the firm is excluded.
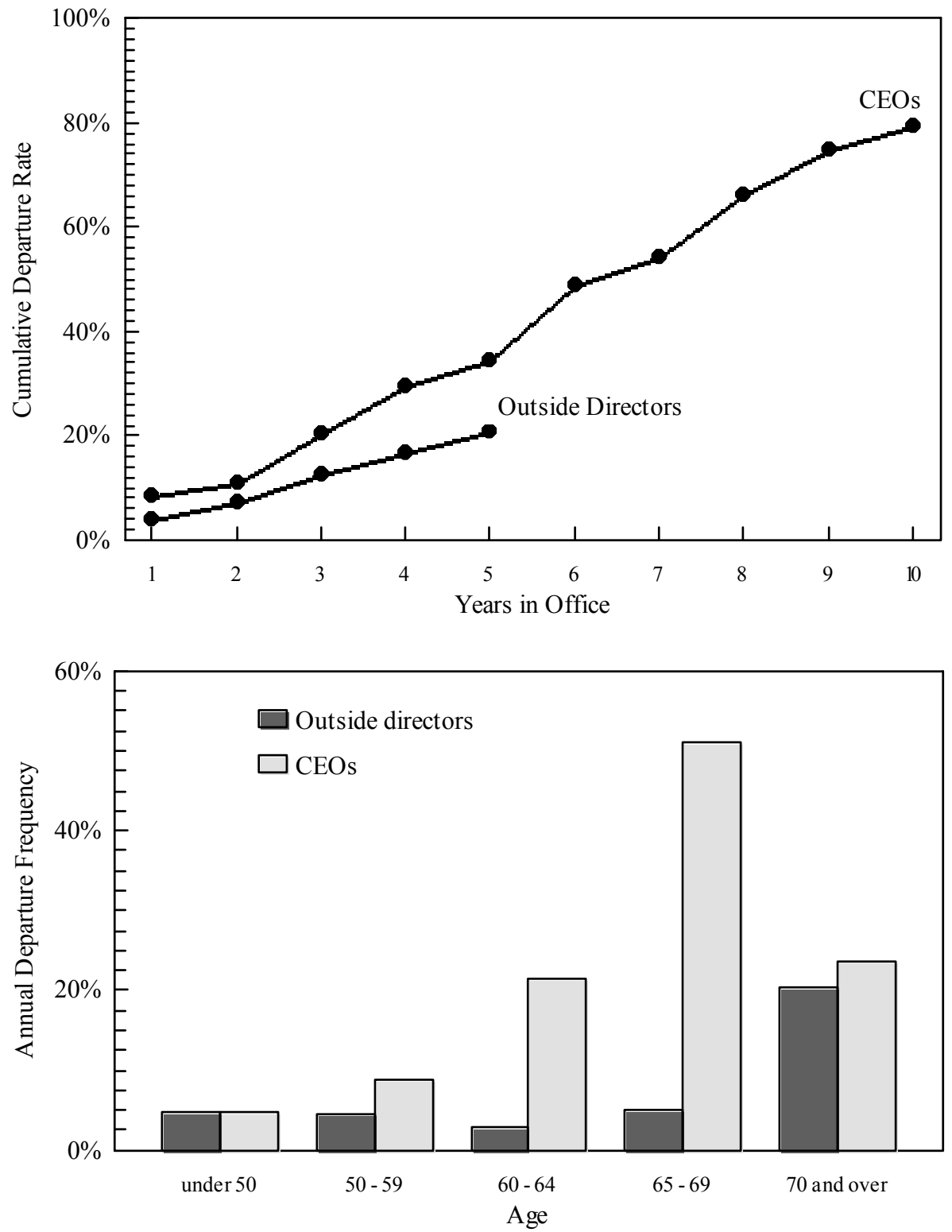


\section{Figure 4}

\section{Retirement rates of outside directors and CEOs, by performance decile}

Retirement frequencies for outside directors appointed to the boards of Fortune 500 companies between 1994 and 1996, compared with retirement rates for the CEOs of the same companies. Data are collected for the first five years in office of each director. The chart shows departure probabilities tabulated within performance deciles, with performance measured as the firm's annual stock return minus the return on the CRSP value-weighted index. Actual departure rates for directors and CEOs in each performance decile are compared with values predicted by the logit regressions shown in Table 5. Turnover due to acquisition or de-listing of the firm is excluded.

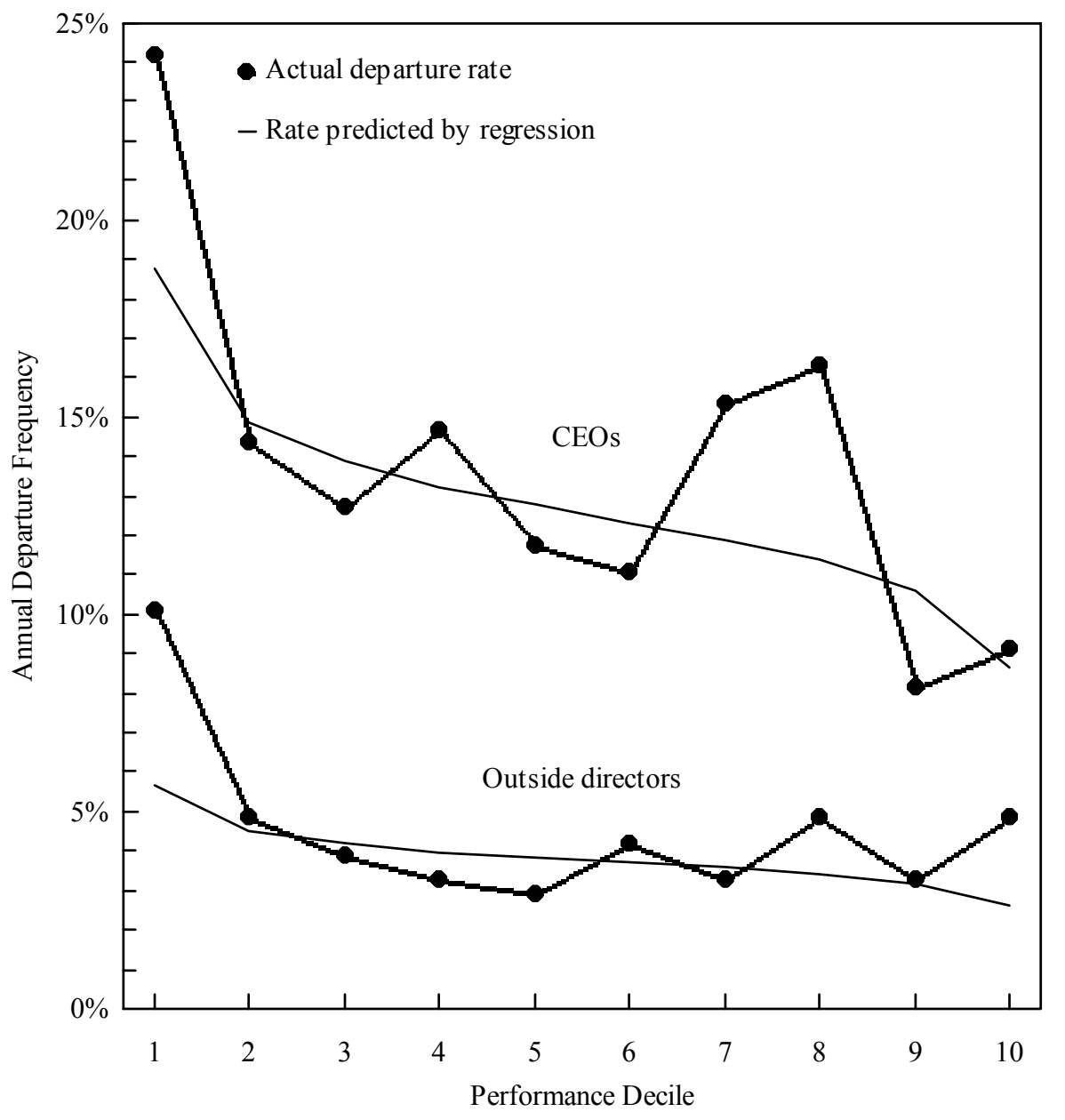




\section{Figure 5}

\section{Change in board seats held by outside directors}

Change in the number of directorships held in other public companies for a sample of 529 outside directors elected to the boards of Fortune 500 companies between 1994 and 1996. The change is calculated over a four-year period from information disclosed in company proxy statements.

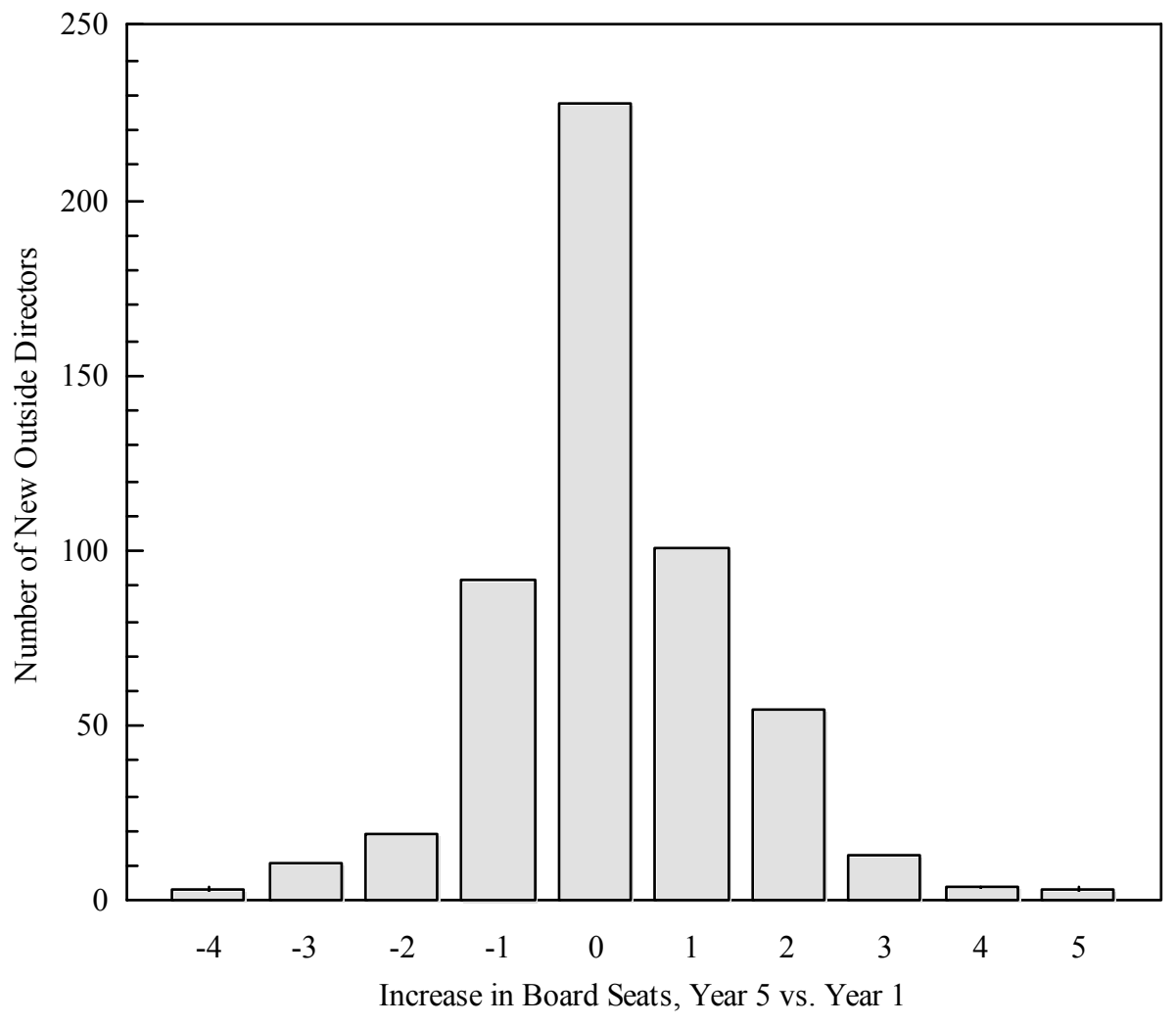




\section{Table 1 \\ Descriptive statistics}

Descriptive statistics for key variables in a sample of 734 outside directors elected to the boards of Fortune 500 companies between 1994 and 1996. Data is obtained from company proxy statements. Grey directors have disclosed conflicts of interest with the firm or its officers. Stock ownership is measured according to the SEC's definition of beneficial ownership. Stock option values are calculated using the Black-Scholes method.

Outside directors in sample

Remaining in sample in fifth year

Retire before fifth year

Firm is delisted before fifth year

Become inside directors before fifth year

Age at election

Female

Grey

Shares held / outstanding

Stock ownership (000)

Other board seats held

Audit committee member

Compensation cmte. member

Cash retainer

Stock retainer

Stock option retainer

Table 2

(000)

(000)

(000)

$\begin{array}{cc}734 & \\ 529 & 72 \% \\ 114 & 16 \% \\ 84 & 11 \% \\ 7 & 1 \%\end{array}$

$\begin{array}{lllll}\frac{\text { Mean }}{54.0} & \frac{\text { Std. Dev. }}{7.4} & \frac{\text { Min. }}{30} & \frac{\text { Median }}{54} & \text { Max. } \\ 0.205 & & & & \\ 0.163 & & & & \end{array}$

$\begin{array}{llllll}\text { first year } & 0.0079 & 0.0788 & 0 & 0.000004 & 0.8808 \\ \text { fifth year } & 0.0052 & 0.0653 & 0 & 0.000047 & 0.8680\end{array}$

first year $\quad \$ 8,572 \quad \$ 84,696 \quad \$ 0 \quad \$ 21 \quad \$ 1,606,588$

fifth year $\$ 8,481 \quad \$ 156,149 \quad \$ 0 \quad \$ 375 \quad \$ 3,583,060$

$\begin{array}{lllllc}\text { first year } & 2.04 & 1.89 & 0 & 2 & 14 \\ \text { fifth year } & 2.27 & 1.73 & 0 & 2 & 9\end{array}$

first year $\quad 0.254$

fifth year $\quad 0.529$

first year $\quad 0.158$

fifth year $\quad 0.453$

$\$ 26.3$

$\$ 10.8$

$0 \quad \$ 25.0$

$\$ 85.0$

non-zero $\quad 0.958$

$\$ 15.5$

$\$ 33.8$

0

0

$\$ 474.5$

non-zero $\quad 0.480$

$\$ 27.8$

$\$ 87.2$

0

0

$\$ 1,364.9$

non-zero $\quad 0.440$ 


\section{Distribution of fees received by outside directors in first five years}

Descriptive statistics for the distribution of retainer fees received by outside directors elected to the boards of Fortune 500 companies between 1994 and 1996. Data is tabulated only for the sub-sample of 529 directors who remain in office at the date of the fifth proxy statement released after their election. The first column reports the aggregate fixed retainer fees received during the first five years of service by each director, including cash, restricted stock awards, and stock options, which are valued according to the Black-Scholes method. The second column shows the appreciation of stock option and restricted stock awards from the award year until the end of the fifth year, with option value changes calculated according to Black-Scholes. Equity awards are assumed to occur at the average monthly closing stock price during the award year. The table does not include further remuneration received by directors, including meeting fees, committee fees, retirement benefits, insurance, and matching charitable contributions. All dollar values are in thousands.

Minimum

5 th percentile

10th percentile

25th percentile

Median

75th percentile

90th percentile

95th percentile

Maximum

Mean

Standard deviation

\section{Sum of \\ Annual \\ Retainers}

$\$ 47$

$\$ 131$

$\$ 158$

$\$ 198$

$\$ 261$

$\$ 375$

$\$ 570$

$\$ 723$

$\$ 3,438$

$\$ 347$

$\$ 341$

\section{Change in Value of Options and Stock Awards}

(\$381)

(\$127)

(\$77)

(\$10)

$\$ 17$

$\$ 101$

$\$ 304$

$\$ 775$

$\$ 53,956$

$\$ 412$

$\$ 3,549$
Total

Received

$\$ 47$

$\$ 122$

$\$ 143$

$\$ 186$

$\$ 286$

$\$ 428$

$\$ 782$

$\$ 1,351$

$\$ 56,707$

$\$ 760$

$\$ 3,771$ 


\section{Table 3}

\section{Determinants of growth in director fees}

Ordinary least squares estimates of the annual percentage change in directors' annual retainers against the annual percentage change in sales and the company's stock return, net of the CRSP value-weighted index. Standard errors robust to heteroskedasticity appear in parentheses below each coefficient estimate. The left three columns use observations from a sample of Forbes 500 companies between 1984 and 1991. The right three columns use data from the current paper's sample, which covers outside directors elected to boards of Fortune 500 companies between 1994 and 1996 and follows them for their first five years in office. I exclude the first year of the 1994-2000 sample because directors often receive large equity awards when joining boards. Both samples exclude firms in the financial and electric utility industries. Directors' retainers include fixed cash compensation, stock awards, and stock option awards. Option awards are valued according to the Black-Scholes approach.

\begin{tabular}{|c|c|c|c|c|c|c|c|c|c|c|c|}
\hline \multirow[b]{3}{*}{ Intercept } & \multicolumn{6}{|c|}{ 1984-1991 sample } & \multicolumn{5}{|c|}{ 1994-2000 sample } \\
\hline & Estimate & & Estimate & & Estimate & & Estimate & & Estimate & & Estimate \\
\hline & $\begin{array}{c}0.070 \\
(11.14)\end{array}$ & $* * *$ & $\begin{array}{c}0.080 \\
(11.98)\end{array}$ & $* * *$ & $\begin{array}{c}0.072 \\
(11.25)\end{array}$ & $* * *$ & $\begin{array}{c}0.093 \\
(10.89)\end{array}$ & $* * *$ & $\begin{array}{c}0.093 \\
(10.58)\end{array}$ & $* * *$ & $\begin{array}{c}0.099 \\
(10.81)\end{array}$ \\
\hline Sales growth & $\begin{array}{l}0.118 \\
(2.36)\end{array}$ & $* *$ & & & $\begin{array}{l}0.100 \\
(2.00)\end{array}$ & $* *$ & $\begin{array}{l}-0.082 \\
(2.29)\end{array}$ & $* *$ & & & $\begin{array}{l}-0.089 \\
(2.43)\end{array}$ \\
\hline $\begin{array}{l}\text { Stock return, } \\
\text { net of market }\end{array}$ & & & $\begin{array}{l}0.073 \\
(2.07)\end{array}$ & $* *$ & $\begin{array}{l}0.060 \\
(1.70)\end{array}$ & $*$ & & & $\begin{array}{l}0.033 \\
(1.98)\end{array}$ & $* *$ & $\begin{array}{l}0.038 \\
(2.32)\end{array}$ \\
\hline Observations & 2,838 & & 2,838 & & 2,838 & & 1,636 & & 1,636 & & 1,636 \\
\hline $\mathrm{R}^{2}$ & 0.0039 & & 0.0034 & & 0.0061 & & 0.0032 & & 0.0018 & & 0.0056 \\
\hline
\end{tabular}

Significant at 1 percent $(* * *), 5$ percent $(* *)$, and 10 percent $(*)$ levels. 


\section{Table 4}

\section{Regression models of outside director turnover}

Logistic regression estimates of the turnover probability for outside directors. The sample includes 734 outside directors elected to the boards of Fortune 500 firms between 1994 and 1996 and includes the first five years in office for each director. Turnover due to acquisition or other de-listing of the firm is excluded. The grey director indicator variable equals 1 if the director has a disclosed conflict of interest with the company or its officers. The indicator for appointing CEO no longer in office equals 1 in years following the departure of the CEO who appointed the director to the board. The stock return variable equals the firm's raw return for the fiscal year, minus the CRSP value-weighted index return, both compounded continuously Standard errors shown in parentheses are robust to heteroskedasticity.

Intercept

Years of service

Age 65 to 69 indicator

Age 70 and over indicator

Percent ownership

Grey

Female

Member of audit committee

Member of compensation committee

CEO departure year

Appointing CEO no longer in office

Stock return, net of market

Stock return, net of market (prior year)

Year indicator variables

Sample size

Significant at 1 percent $(* * *), 5$ percent $(* *)$, and 10 percent $(*)$ levels.

\section{$\underline{\text { Estimate }}$}

$-2.11$

(0.73)

$-0.12$

(0.13)

0.04

(0.29)

1.79

(0.38)

0.31

(0.87)

0.33

(0.22)

$-0.77$

(0.30)

$-0.29$

(0.19)

$-0.50$

(0.22)

0.86

$(0.22)$

0.59

(0.23)

$-0.56$

(0.24)

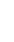

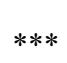

\section{Estimate \\ $-2.12$ \\ (0.73)}

$-0.12$

(0.13)

0.04

$(0.29)$

1.78

(0.38)

0.24

(0.93)

0.33

(0.22)

$-0.77$

(0.30)

$-0.29$

(0.19)

$-0.50$

(0.22)

0.85

(0.22)

0.59

(0.23)

$-0.56$

$(0.24)$

$-0.07$

$(0.24)$

Yes Yes 


\section{Table 5}

\section{Outside director turnover compared to CEO turnover}

Marginal effects of a unit change in various explanatory variables upon the probability of departure for outside directors and CEOs. Statistics are calculated using a logistic regression model, substituting coefficient estimates and sample means of each variable into the partial derivative of the likelihood function. Variable definitions and the description of the outside director sample are the same as in Table 4. Statistical significance is based on regression standard errors robust to heteroskedasticity.

\begin{tabular}{|c|c|c|c|}
\hline & Outside & & \\
\hline & Director & & CEOs \\
\hline Years of service & -0.001 & & $0.003 * * *$ \\
\hline Age 65 to 69 indicator & 0.000 & & $0.208 * * *$ \\
\hline Age 70 and over indicator & 0.064 & $* * *$ & 0.046 \\
\hline Female & -0.030 & $* * *$ & 0.105 \\
\hline CEO departure year & 0.033 & $* * *$ & \\
\hline Appointing CEO no longer in office & 0.020 & $* *$ & \\
\hline Stock return, net of market & -0.022 & $* * *$ & $-0.073 * * *$ \\
\hline Sample size & 3,062 & & 3,062 \\
\hline Unconditional departure frequency & 0.046 & & 0.138 \\
\hline
\end{tabular}

Significant at 1 percent $(* * *), 5$ percent $(* *)$, and 10 percent $(*)$ levels. 


\section{Table 6}

\section{Additional board seats obtained by outside directors}

Ordinary least squares estimates of the number of board seats acquired by outside directors during their first four years of service on the boards of Fortune 500 companies. The sample includes 529 directors elected to company boards between 1994 and 1996, who continue to serve as directors of the same companies four years later. Information about board seats is limited to other public companies and is collected from director biographies published in the first and fifth annual proxy statements in which a director appears. Standard errors robust to heteroskedasticity appear in parentheses.

Intercept

Grey

Female

Number of other board seats held when elected

Company rank in Fortune 500

Stock return, net of market

Stock return, net of market, lagged one year

Occupation indicator variables

Sample size

$\mathrm{R}^{2}$

\section{Estimate}

1.08

(0.31)

$-0.25 *$

$(0.15)$

$-0.19$

$-0.30 * * *$

$-0.0005$

$(0.0003)$

0.12

$(0.12)$

$0.34 \quad * *$

(0.15)

Yes

3,062

0.23

Significant at 1 percent $(* * *), 5$ percent $(* *)$, and 10 percent $(*)$ levels. 


\section{References}

Avery, Christopher, Judith A. Chevalier, and Scott Schaefer, 1998, Why do managers undertake acquisitions? An analysis of internal and external rewards for acquisitiveness. Journal of Law, Economics, and Organization 14, 24-43.

Baker, George P., Michael C. Jensen, and Kevin J. Murphy, 1988, Compensation and incentives: Practice vs. theory. Journal of Finance 43, 593-616.

Booth, James R., and Daniel N. Deli, 1996, Factors affecting the number of outside directorships held by CEOs. Journal of Financial Economics 40, 81-104.

Brickley, James A., James S. Linck, and Jeffrey L. Coles, 1999, What happens to CEOs after they retire? New evidence on careeer concerns, horizon problems, and CEO incentives. Journal of Financial Economics 52, 341-377.

Brown, William O., and Michael T. Maloney, 1999, Exit, voice, and the role of corporate directors: Evidence from acquisition performance. Unpublished manuscript, Claremont McKenna College.

Coles, Jeffrey L., and Chun Keung Hoi, 2001, New evidence on the market for directors: Board membership and Pennsylvania Senate Bill1310. Journal of Finance, forthcoming.

Fama, Eugene F., and Michael C. Jensen, 1983, Separation of ownership and control. Journal of Law and Economics 26, 301-325.

Farrell, Kathleen A., and David A. Whidbee, 2000, The consequences of forced CEO succession for outside directors. Journal of Business 73, 597-628.

Ferris, Stephen P., Murali Jagannathan, and Adam C. Pritchard, 2002, Too busy to mind the business? Monitoring by directors with multiple board appointments. Journal of Finance, forthcoming.

Gilson, Stuart C., 1990, Bankruptcy, boards, banks, and bondholders: Evidence on changes in corporate ownership and control when firms default. Journal of Financial Economics 27, 355388.

Harford, Jarrad, 2001, Takeover bids and target directors' incentives: The impact of a bid on directors wealth and board seats. Journal of Financial Economics, forthcoming.

Hermalin, Benjamin E., and Michael S. Weisbach, 1988, The determinants of board composition. RAND Journal of Economics 19, 589-606.

Kaplan, Steven N., and David Reishus, 1990, Outside directorships and corporate performance. 
Journal of Financial Economics 27, 389-410.

Murphy, Kevin J., 1999, Executive compensation, in Orley Ashenfelter and David Card (eds.), Handbook of Labor Economics, Vol. 3, North-Holland.

Perry, Tod, 2000, Incentive compensation for outside directors and CEO turnover. Unpublished manuscript, Arizona State University.

Shivdasani, Anil, and David Yermack, 1999, CEO involvement in the selection of new board members: An empirical analysis. Journal of Finance 54, 1829-1853.

Vafeas, Nikos, 1999, Board meeting frequency and firm performance. Journal of Financial Economics 53,113-142.

Warner, Jerold B., Ross L. Watts and Karen H. Wruck, 1988, Stock prices and top management changes. Journal of Financial Economics 20, 461-492.

Yermack, David, 1995, Do corporations award CEO stock options effectively? Journal of Financial Economics 39, 237-269. 